\title{
Effects of obesity on liver cytochromes P450 in various animal models
}

\author{
Veronika Tomankova ${ }^{a}$, Pavel Anzenbacher ${ }^{b}$, Eva Anzenbacherova ${ }^{a}$
}

\begin{abstract}
The prevalence of obesity and other obesity-related diseases is increasing worldwide. Obesity is a disease characterized by increased body weight, or a condition resulting from excessive accumulation of body fat. Due to increased body fat deposits, obesity has also been associated with increased mortality resulting from higher incidence rates of hypertension, diabetes, or various types of cancer, such as breast, colorectal, cervical and prostate cancer. Physiological changes associated with obesity are likely to result in altered drug biotransformation. The main enzymes enabling the oxidative biotransformation of most drugs are cytochromes P450 (CYPs). The review summarizes how pathophysiological factors, especially obesity, affect properties (e.g. enzyme activity, protein expression, gene expression) of CYP enzymes in various experimental models of human obesity. Results reported by various authors suggest that obesity is associated with a decrease of CYP activities (except for the CYP2C and CYP2E1 enzymes). The only exception is mouse obesity induced by monosodium glutamate (administered to newborn mice) as it usually leads to increased CYP expression. Selecting an animal model that is as close as possible to the properties of human obesity is of paramount importance.
\end{abstract}

Key words: obesity, animal model, cytochrome P450, drug metabolism, enzyme activity, protein level, mRNA level

Received: June 14, 2016; Accepted: May 11, 2017; Available online: May 25, 2017

https://doi.org/10.5507/bp.2017.026

${ }^{a}$ Department of Medical Chemistry and Biochemistry, Faculty of Medicine and Dentistry, Palacky University Olomouc, Czech Republic ${ }^{b}$ Department of Pharmacology, Faculty of Medicine and Dentistry, Palacky University Olomouc and University Hospital Olomouc, Czech Republic

Corresponding author:Eva Anzenbacherova, e-mail:eva.anzenbacherova@upol.cz

\section{INTRODUCTION}

Obesity is a serious metabolic disorder that has become a global health problem. It is often considered a low-grade inflammatory condition ${ }^{1}$ resulting in several chronic human diseases ${ }^{2-4}$ including hypertension, diabetes ${ }^{5}$ and various types of cancer, such as breast, endometrial, colorectal, cervical, ovarian, stomach and prostate cancer $^{3,6}$. As mentioned previously, obesity results from excessive accumulation of body fat ${ }^{5}$. To classify the overweight status and obesity in adults, the body mass index (BMI) is commonly used that is calculated by dividing weight (in kilograms) by the square of height (in meters). Overweight occurs when BMI $\geq 25$, obesity is defined as BMI $\geq 30$ (ref. $^{7}$ ). According to the World Health Organization, around two billion adults aged 18 years and above were overweight in 2014. Of these, more than 600 million were obese. If the prevalence of obesity continues to rise linearly, $51 \%$ of the population will become obese in 2030 (ref. $\left.^{8}\right)$.

Physiological changes associated with obesity are also likely to involve altered drug metabolism and clearance of drugs ${ }^{2,9}$. These may lead to an increased risk of adverse drug effects and drug interactions in obese individuals. Therefore, it is very important to know whether enzymes involved in biotransformation of drugs are influenced by pathological conditions in individuals with obesity ${ }^{5,9,10}$; animal models are commonly used to investigate the corresponding consequences.

\section{DRUG-METABOLIZING ENZYMES}

Drug metabolism is mainly carried out by drug-metabolizing enzymes which correspond to two phases of biotransformation (phase I and phase II). Cytochrome P450 (CYP) enzymes belong to phase I of biotransformation and represent a superfamily of heme-containing enzymes ${ }^{9,11}$. Phase I of biotransformation of foreign compounds includes oxidation, reduction or hydrolysis converting the parent substance to a more polar metabolite ${ }^{12}$. Almost sixty CYP enzymes have been found in the human genome. CYP enzymes are essential for detoxification of foreign chemicals (xenobiotics) and for metabolism of many medications $s^{13,14}$. Human CYP enzymes participate in the biotransformation of most xenobiotics including more than two thirds of all medications in clinical use. The most important CYP enzymes participating in drug metabolism include CYP1A1, CYP1A2, CYP2A6, CYP2B6, CYP2C8, CYP2C9, CYP2C19, CYP2D6, CYP2E1, CYP3A4 and CYP3A5 (ref. ${ }^{13,15}$ ). Most CYP enzymes in the human organism are primarily expressed in the liver ${ }^{13}$, but they are also present in the small intestine, heart, lungs, placenta, kidneys and other organs $\mathbf{s}^{14}$. The most common form expressed in the human liver which metabolizes almost one half of marketed drugs is CYP3A4 (ref. ${ }^{13}$ ).

In the following subsections, the most important CYP enzymes participating in drug metabolism are presented. Also, the results of animal and/or human studies that 
describe the effects of pathophysiological factors, particularly obesity, on the properties of CYP enzymes are discussed.

\section{Subfamily of CYP1A enzymes}

The human CYP1A subfamily includes two main members, CYP1A1 and CYP1A2 (ref. ${ }^{11}$ ). The CYP1A1 form is predominantly expressed extrahepatically; in the liver, it is expressed as a result of induction, for example by polycyclic aromatic compounds. On the contrary, the CYP1A2 form is mostly expressed in the human liver ${ }^{13}$ and either not or only weakly expressed in extrahepatic tissues ${ }^{16}$. CYP1A2 plays a more important role in drug metabolism than CYP1A1 (ref. ${ }^{17}$ ). Human hepatic CYP1A2 accounts for approximately $13 \%$ of total hepatic CYP content and is responsible for metabolism of $\sim 10 \%$ of marketed drugs ${ }^{13,16}$. Various substrates are metabolized via the CYP1A2 enzyme, including caffeine ${ }^{18}$ and theophylline ${ }^{9}$.

Metabolism of specific probes of CYP1A2 activity has been studied in obese in comparison with non-obese populations ${ }^{19}$. A recent study focused on determining the oxidative enzyme activity of CYP1A2 in non-obese and obese children using caffeine as a probe substrate. The authors found no changes in CYP1A2 activity in urine samples between non-obese and obese children ${ }^{18}$.

Similarly, no changes or no significant changes were found in two animal studies. An in vivo study showed no significant differences in CYP1A activity when comparing lean and $o b / o b$ mice; ethoxyresorufin was used as a probe for CYP1A activity ${ }^{20}$. The other study revealed unaltered expression of Cypla2 in high-fat diet mice ${ }^{9}$.

Yoshinari et al. ${ }^{21}$ provided data showing that mRNA levels of the Cypla2 gene did not differ between $d b / d b$ mice and control animals. However, protein expression of CYP1A2 tended to decrease in $d b / d b$ mice. Also in our recent study ${ }^{10}$ of obese mice, no tendency to reduction of mRNA and protein expression was detected. On the contrary, significantly increased CYP1A2 activity in monosodium glutamate (MSG)-obese mice was found.

Obese individuals are more susceptible to cancers of the breast, cervix, ovary and uterus. 7,12-Dimethylbenz(a) anthracene is used as a model compound for inducing mammary carcinogenesis in rodents. Hakkak et al. ${ }^{22}$ used 40-day-old ovariectomized obese and non-obese Zucker diabetic fatty (ZDF) rats. The authors observed significantly higher protein expression of CYP1A2 in the liver of obese ZDF rats compared to their lean counterparts. ZDF rats were also used for determining protein expression of drug-metabolizing enzymes in pre-diabetic and diabetic animals. Suh et al. ${ }^{23}$ reported significantly decreased mRNA expression of the Cypla2 gene in diabetic animals. On the other hand, mRNA expression of the Cypla2 gene in pre-diabetic animals was increased.

Similar to $d b / d b$ mice, inbred Wistar rats are used as a rat model for type 2 diabetes research. Inbred male Wistar rats were used to study whether lipid accumulation in early steatotic liver affects CYP expression. The results showed significantly decreased CYP1A protein expression in rats with hepatic steatosis as compared to controls ${ }^{24}$. This finding corresponds to results from the studies of $d b / d b$ mice by Yoshinari et al. ${ }^{21}$ study and of ZDF rats by Suh et al. ${ }^{23}$.

The other member of the CYP1A family is the CYP1A1 enzyme which is also active in drug metabolism; it is expressed in the placenta and also in the fetal liver. An interesting study comparing CYP1A1 activity in full-term placentas of obese and non-obese women counterparts was performed by DuBois et al. ${ }^{25}$. Furthermore, CYP1A1 activity in fetal liver from a primate (non-human) model of maternal obesity was determined in the same study. The microsomal activity of CYP1A1 was significantly decreased in placentas of obese women. On the other hand, cytosolic CYP1A1 activity was not affected. In fetal liver of non-human primates, the same results were found, that is, a decrease in microsomal CYP1A1 activity ${ }^{25}$.

The results of various studies indicate that obesity may affect CYP1A enzyme levels in the organism. However, many factors play a role, especially the model of obesity that is used.

\section{Subfamily of CYP2A enzymes}

The subfamily of CYP2A enzymes in humans includes the CYP2A6, CYP2A7 and CYP2A13 forms ${ }^{13}$. Of those, CYP2A6 is the most important enzyme involved in drug metabolism. It is predominantly expressed in the liver ${ }^{26}$ and accounts for $\sim 4 \%$ of CYP in the human liver ${ }^{13}$. It is responsible for metabolism of about $3 \%$ of marketed drugs $^{13}$. The most significant CYP2A6 substrates are coumarin and nicotine ${ }^{27,28}$. In addition to these substrates, CYP2A6 metabolizes many drugs, toxic compounds or procarcinogens $^{13,28,29}$ (some of them are listed in Table 1). CYP2A6 is also involved in the metabolism of bilirubin as an endogenous substrate ${ }^{30}$.

Table 1. Typical substrates, inhibitors and inducers of the human CYP2A6 enzyme.

\begin{tabular}{|c|c|c|c|}
\hline Enzyme & Substrates & Inhibitors & Inducers \\
\hline \multirow{7}{*}{ 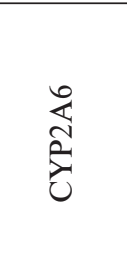 } & Cotinine $^{58}$ & 8-Methoxypsoralen ${ }^{28}$ & Carbamazepine $^{61}$ \\
\hline & Coumarin 59 & Tranylcypromine ${ }^{60}$ & Dexamethasone $^{13}$ \\
\hline & Disulfiram $^{58}$ & Tryptamine ${ }^{60}$ & Phenobarbital $^{62}$ \\
\hline & Efavirenz $^{13}$ & Menthofurane $\mathrm{e}^{58}$ & Rifampicin ${ }^{13}$ \\
\hline & Halothan $^{28}$ & Pilocarpine $^{13}$ & \\
\hline & Nicotine $^{27}$ & & \\
\hline & Valproic acid ${ }^{28}$ & & \\
\hline
\end{tabular}


A human in vitro study showed significantly decreased CYP2A6 enzyme activity in human fat-overloaded hepatocytes compared with control samples ${ }^{31}$.

On the other hand, an animal study using MSG-treated mice showed significantly increased murine CYP2A5 enzyme activity, protein and mRNA expression when compared to control mice. Coumarin was used as a substrate for determination of CYP2A5 activity in mice ${ }^{10}$. Similarly, Watson et al. reported increased CYP2A activity (testosterone $7 \alpha$-hydroxylation) in $o b / o b$ mice in comparison with lean mice ${ }^{20}$.

\section{Subfamily of the CYP2B enzyme}

Although the role of the CYP2B6 enzyme in obesity is not significant, it significantly contributes to drug metabolism ${ }^{32}$. This enzyme metabolizes $\sim 8 \%$ of clinically used drugs $^{13}$. Bupropion, pethidine, propofol and ketamine are drugs metabolized by CYP2B6 (ref. ${ }^{33}$ ). It is also partly involved in the metabolism of nicotine ${ }^{34}$. This enzyme accounts for $\sim 3-6 \%$ of the total CYP content in the liver ${ }^{33}$.

Watson et al. reported significantly increased CYP2B activity in male $o b / o b$ mice compared to their lean counterparts. In their study, pentoxyresorufin was used as a marker of CYP2B activity ${ }^{20}$. Furthermore, an in vivo study of $d b / d b$ mice found significantly increased CYP2B 10 protein as well as Cyp $2 b 10$ mRNA levels as compared with a control group ${ }^{21}$. According to Cheng et al., it is very important to take into account gender specificity. Their study showed decreased mRNA expression of the Cyp $2 b 10$ gene in the liver of female $o b / o b$ mice as compared with control mice. Conversely, mRNA expression of Cyp $2 b 10$ was increased in male $o b / o b$ mice $^{32}$.

The use of rat models of obesity often leads to results different from those in mouse obesity models. In a study focused on determination of Cyp $2 b 2$ mRNA expression in an obese Zucker rat model ${ }^{35}$, decreased mRNA levels of this gene in the liver were observed. On the other hand, Zucker rats exhibited alterations in transcription ${ }^{35}$.

\section{Subfamily of CYP2C enzymes}

The subfamily of CYP2C enzymes consists of the following forms: CYP2C8, CYP2C9 and CYP2C19. The members of the CYP2C subfamily account for $\sim 20 \%$ of human hepatic CYP content. The CYP2C8 form is not very important in drug metabolism ${ }^{13,11}$. The latter forms of this subfamily metabolize $10 \%$ and $5 \%$ of drugs, respectively ${ }^{19}$. All forms in the CYP2C subfamily possess genetic polymorphism ${ }^{36}$.

CYP2C9 is the major enzyme of the CYP2C subfamily in the human liver. This form metabolizes clinically important medications including antidiabetics (e.g. tolbutamide, glipizide), anticonvulsants (e.g. phenytoin), anticoagulants (e.g. warfarin) and several anti-inflammatory drugs (e.g. ibuprofen) (ref. ${ }^{13,19,36}$ ). The anticoagulant drug warfarin exists in two forms ( $\mathrm{R}$ - and S-enantiomer). The S-enantiomer of warfarin is predominantly metabolized by CYP2C9 $\left(\right.$ ref. $^{37}$ ). Some steroids and arachidonic acid are endogenous compounds which may also be metabolized by CYP2C9 $\left(\right.$ ref. $^{13}$ ).
CYP2C19 was the first CYP2C enzyme in which the genetic polymorphism in the metabolism of mephenytoin was discovered ${ }^{13}$. According to population studies, individuals can be classified as poor or extensive metabolizers of this drug. The S-enantiomer is more rapidly hydroxylated than the R-enantiomer ${ }^{13,36}$. CYP2C19 metabolizes various therapeutic agents including anticonvulsants (e.g. mephenytoin, felbamate ${ }^{36,38}$ ), antidepressants (e.g. amitriptyline, imipramine $^{13,36,39}$ ), benzodiazepines (e.g. diazepam ${ }^{13}$ ) and antiulcer drugs (e.g. omeprazole ${ }^{36}$ ). CYP2C19 also metabolizes endogenous substrates, such as progesterone and melatonin ${ }^{13}$.

The effect of obesity on CYP2C enzyme activity and expression, using both animal models and humans, was investigated in several studies. A human study showed only slightly increased CYP2C9 activity in obese individuals $^{19}$. In the study, the anticonvulsant phenytoin, the antiinflammatory ibuprofen and the antidiabetics glimepiride and glipizide were used as CYP2C9 substrates. Higher activity was also observed for the CYP2C19 enzyme in obese than in non-obese individuals. Diazepam was used as a CYP2C19 substrate. Interestingly, in the obese group, no changes in CYP2C19 activity were observed when desmethyldiazepam was used as a substrate ${ }^{19}$.

Studies with the $d b / d b$ mouse model reported no significant differences in protein expression of CYP2Cs. On the other hand, the mRNA level of Cyp2c29 was significantly increased in $d b / d b$ mice compared to a control group ${ }^{21}$. In a study with mice treated with MSG for induction of obesity, no significant changes in CYP2C enzyme activity, protein expression and gene expression were found as compared to control mice ${ }^{10}$.

In an in vivo experiment with ZDF rats, researchers found significantly decreased expression of the Cyp $2 c 39$ gene in 12-week-old ZDF rats. Cyp2c39 gene expression was increased in 6-week-old ZDF rats. This suggests that the liver of 12-week-old ZDF rats has an impaired ability to manage oxidative stress and certain xenobiotics ${ }^{23}$. Zhang et al. reported significantly decreased protein expression of rat hepatic microsomal CYP2C11 in early steatosis $^{24}$.

\section{Subfamily of the CYP2D enzyme}

There is a single protein-coding gene in the human subfamily CYP2D named CYP2D6 ( ref. $^{13}$ ). This enzyme is expressed in the human liver and represents only about $4 \%$ of total CYP ( ref. $^{16}$ ). CYP2D6 has been characterized as a typically polymorphic drug-metabolizing enzyme ${ }^{40}$. The genetic polymorphism causes the presence of three major phenotypes of oxidative metabolism divided into the following groups: slow, rapid and ultrarapid metabolizers (from null alleles to multiple gene amplification) (ref. ${ }^{13,11}$ ). This enzyme metabolizes about $20 \%$ of therapeutic agents ${ }^{13}$, such as antidepressants (e.g. nortriptyline, paroxetine, fluoxetine), neuroleptics (e.g. haloperidol, zuclopenthixol), antiarrhythmics (e.g. propafenone, mexiletine), $\beta$-adrenoreceptor blockers (metoprolol, propranolol, bufuralol) (ref. ${ }^{13,16,40}$ ) and others.

There are only a few studies dealing with the influence 
of obesity on CYP2D6 expression and activity. Donato et al. ${ }^{31}$ studied the in vitro effect of lipid accumulation on various CYP enzymes including CYP2D6. Human hepatocytes were incubated with long chain free fatty acids ${ }^{41}$ to induce lipid accumulation; a decreased CYP2D6 enzyme activity was observed. The decrease in CYP2D6 activity in human hepatocytes with excess fat may be due to a decreased mRNA level of this gene. On the contrary, Cheymol et al. ${ }^{42}$ showed increased CYP2D6 activity in obese subjects; nebivolol was used as a CYP2D6 substrate.

An in vivo study showed no differences in CYP2D enzyme activity, protein and mRNA expression between normal mice and MSG-obese animals ${ }^{10}$. The results of individual studies vary; therefore, further studies are needed to confirm or refute the changes found in CYP2D expression and activity.

\section{Subfamily of the CYP2E enzyme}

The mammalian subfamily CYP2E only includes the CYP2E1 gene. The human CYP2E1 enzyme form constitutes $3 \%$ of the total hepatic content of CYP. This enzyme is known to take part especially in the metabolism of ethanol ${ }^{13,11}$. Patients addicted to alcohol may be at increased risk of hepatotoxicity of acetaminophen (paracetamol) because of CYP2E1 induction by alcohol, leading to production of a reactive, toxic compound ${ }^{43}$. In addition to the metabolism of ethanol as a CYP2E1 inducer, this enzyme is also involved in the metabolism of acetone and other known CYP2E1 inducers ${ }^{13,11}$. Prolonged exposure to compounds (in large amounts) that induce this single form of the CYP2E subfamily may cause formation of free radicals, lipid peroxidation and liver damage ${ }^{7}$. The examples of CYP2E1 inhibitors, inducers and substrates are listed in Table 2. The CYP2E1 enzyme is involved in the metabolism of only about $5 \%$ of drugs on the market.

Despite lower mRNA expression of Cyp2el and its limited involvement in drug metabolism, the effect of obesity on CYP2E1 activity has been described in several studies $^{19}$. Obesity is considered to be one of the inducers of the CYP2E1 enzyme ${ }^{37}$.

A common comorbidity of obesity is nonalcoholic fatty liver disease; therefore, the hepatic metabolism via CYP2E1 is very important in obesity ${ }^{7}$. Most studies of both human and animal obesity demonstrated increased activity and expression at protein and mRNA levels of the CYP2E1 enzyme. As a selective probe, chlorzoxazone is widely used to study the impact of obesity on CYP2E1 activity $^{10,44,45}$.

A study of obesity using human liver microsomal fractions prepared from diabetic and demographically matched nondiabetic donors observed enhanced CYP2E1 activity in diabetic fractions ${ }^{44}$. Also, an increased CYP2E1 activity (using chlorzoxazone as a probe substrate) was observed in obese patients in comparison with non-obese ones $^{19}$.

In an animal study using mice with MSG-induced obesity, significantly increased activity and protein expression of hepatic CYP2E1 in obese mice was found. Also, in the small intestine and colon of obese mice, increased expression of Cyp2el compared to their lean counterparts was observed $^{10}$.

Conversely, significantly decreased activity of CYP2E1 was observed in $o b / o b$ mice $^{20}$. Gene expression of Cyp2el was decreased in the liver of female as well as male $o b / o b$ mice. Decreased mRNA expression of the Cyp $2 e 1$ gene in male $o b / o b$ mice was in accordance with protein expression. However, protein expression of CYP2E1 in female $o b / o b$ mice liver did not differ between obese and control mice $^{32}$. In another study with $o b / o b$ mice, significantly decreased CYP2E1 expression of protein and mRNA was observed in females; males also exhibited decreased expression but not significantly ${ }^{46}$. Significantly decreased CYP2E1 enzyme activity was seen in the liver of ZDF rats as well as in $o b / o b$ mice of both genders. In male ZDF rats, significantly decreased protein expression and non-significantly decreased mRNA expression were observed $^{46}$. No significant changes in CYP2E1 protein expression as well as in expression of the Cyp2el gene in $d b / d b$ mice were found ${ }^{21}$.

The induction of CYP2E1 in the liver and fat was investigated in three groups of Zucker rats: normal Zucker rats fed with a normal diet (ND), normal Zucker rats fed with a high-fat diet (HF) and genetically obese Zucker rats fed with a normal diet (OB). Higher induction of the CYP2E1 protein in both liver and fat was observed in OB rats compared to HF rats. CYP2E1 activity was also increased in $\mathrm{OB}$ rats. In the liver, slightly higher mRNA expression of Cyp2el in HF and OB rats compared to ND rats was observed. In the fat, significantly higher mRNA expression of CYP2E1 in HF and OB rats compared to ND rats was seen ${ }^{45}$. An exception to rat obesity models was a study by Zhang et al. where significantly decreased protein expression of CYP2E1 was observed in male

Table 2. Examples of substrates, inhibitors and inducers of the human CYP2E1 enzyme.

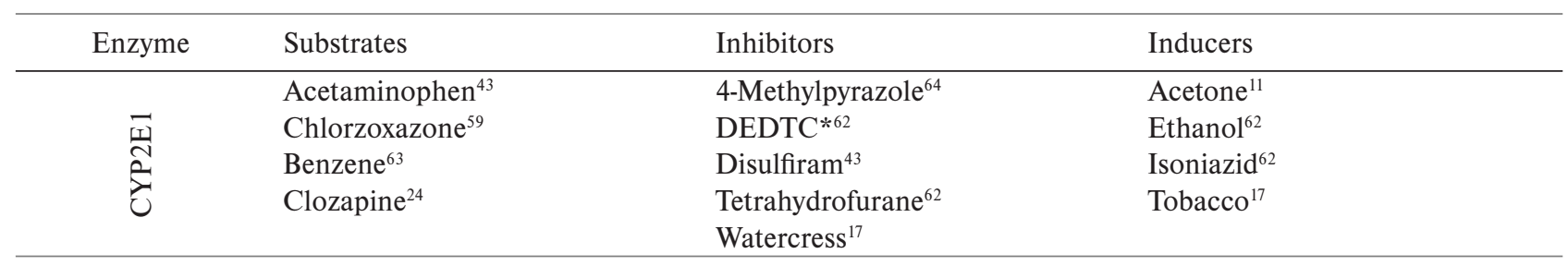

\footnotetext{
* DEDTC - N,N-diethyldithiocarbamate
} 
Wistar rats. Clozapine was used as a probe for CYP2E1 activity and the study reported decreased activity of the CYP2E1 enzyme ${ }^{24}$.

\section{Subfamily of CYP3A enzymes}

The CYP3A subfamily in humans consists of the following four CYP genes: CYP3A4, CYP3A5, CYP3A7 and CYP3A43 (ref. ${ }^{13}$ ). CYP3A4 and CYP3A5 are the most abundant enzymes located in the human liver and gastrointestinal tract during adult life. On the other hand, in the fetal liver and uterine endometrium, the CYP3A7 enzyme is expressed. However, the amount of this enzyme rapidly decreases in the first weeks of life ${ }^{47}$. Finally, the function of the hepatic CYP3A43 enzyme is not yet known ${ }^{44,48}$. The CYP3A4 enzyme is the most important CYP form essential for detoxification of xenobiotics and metabolism of most drugs ${ }^{11}$. This form constitutes about $30 \%$ of liver CYP ( ref. $^{13}$ ). It is also responsible for several clinically significant drug-drug interactions (e.g. interactions of statins, azoles, antivirals) $\left(\right.$ ref. $\left.{ }^{17}\right)$. Its active site is large, adaptable and it can hold and metabolize many lipophilic compounds, such as immunosuppressants (e.g. cyclosporine A, tacrolimus), anticancer drugs (e.g. taxol) and many others ${ }^{13}$. There are studies reporting the effect of obesity on the CYP3A enzyme. There are a few specific substrates for determination of enzyme activity of CYP3A, such as testosterone ${ }^{10}$ or midazolam ${ }^{44}$. Additional specific substrates of the CYP3A4 enzyme are summarized in Table 3.

With regard to the effect of diabetes on CYP activity and expression, there are differences between humans and animals. In fact, these may stem from several factors, such as gender, age, degree of diabetes or duration of the disease $^{49}$. One of the studies dealing with the influence of obesity on CYP enzyme activity and expression reported a significant decrease in CYP3A4 enzyme activity and protein level in human liver microsomal fractions from diabetic donors. This study indicates that diabetes is associated with a significant reduction in liver CYP3A4 enzyme activity and protein expression ${ }^{44}$.

Brill et al. ${ }^{19}$ reported results of a clinical study showing the values of the clearance of CYP3A4 substrates in obese and non-obese patients. The authors found that obesity was associated with significantly lower clearance for most CYP3A4 substrates. Their results correspond with data from an earlier study ${ }^{50}$. Clearance of N-methylerythromycin and triazolam as CYP3A4 probes $^{51}$ was significantly lower in obese patients compared to non-obese ones. Also alprazolam, cyclosporine and midazolam showed a trend towards decreased clearance values in obese individuals ${ }^{19}$. Taranabant, which is metabolized by CYP3A4, is used for weight loss and reduced fat mass; clearance of this drug was also decreased in obese individuals in comparison to their non-obese counterparts ${ }^{52}$. These results are attributed to either reduction in CYP3A enzyme activity or to increased binding to proteins ${ }^{19}$.

A study using male ICR mice fed with two different high-fat diet (HFD) types (36\% kcal from fat for 5 weeks and $32 \% \mathrm{kcal}$ from fat for 40 days) reported altered protein and mRNA levels of the most important biotransformation enzyme CYP3A. The experiment demonstrated a significant decrease of CYP3A protein and Cyp 3 all gene expression in the mice liver with nutritionally induced obesity $^{53}$. Other authors used adult male CD1 mice fed with HFD (60\% kcal from fat) as an experimental group and low-fat diet ( $10 \% \mathrm{kcal}$ from fat) as a control group (both groups were fed for 14 weeks). Cyp $3 a 11$ gene expression was significantly decreased in the HFD mice compared to the control animals. The observed decrease in mRNA level of Cyp3all gene was confirmed by decreased enzyme activity. Midazolam was used as a CYP3A4 substrate ${ }^{54}$. In a study of $o b / o b$ mice, expression of the Cyp $3 a 11$ gene

Table 3. Overview of substrates, inhibitors and inducers of the human CYP3A4 enzyme.

\begin{tabular}{|c|c|c|c|}
\hline Enzyme & Substrates & Inhibitors & Inducers \\
\hline 离 & $\begin{array}{l}\text { Amitriptyline } \\
\text { Cyclosporine }^{65} \\
\text { Diazepam }^{43} \\
\text { Domperidone }^{66} \\
\text { Erythromycin }^{62} \\
\text { Clarithromycin }^{67} \\
\text { Etoposide }^{63} \\
\text { Indinavir }^{68} \\
\text { Lidocaine }^{43} \\
\text { Midazolam }^{62} \\
\text { Nifedipine (and dihydropyridine drugs }^{62} \\
\text { Phenacetin } \\
\text { Sildenafil }^{69} \\
\text { Simvastatin }^{43} \\
\text { Testosteron }^{59} \\
\text { Taxol }^{13} \\
\text { Verapamil }^{63} \\
\text { Tacrolimus }^{13}\end{array}$ & $\begin{array}{l}\text { Itraconazole }^{43} \\
\text { Ketoconazole }^{62} \\
\text { Fluconazole }^{43} \\
\text { Erythromycin }^{43} \\
\text { TAO*70 } \\
\text { Amiodarone }^{17} \\
\text { Cimetidine }^{17} \\
\text { Gestodene }^{62} \\
\text { Grapefruit juice }^{43} \\
\text { Omeprazole }^{17}\end{array}$ & $\begin{array}{l}\text { Carbamazepine }^{62} \\
\text { Dexamethasone }^{62} \\
\text { Phenobarbital }^{62} \\
\text { Phenytoin }^{43} \\
\text { Rifabutin }^{43} \\
\text { Rifampicin }^{62}\end{array}$ \\
\hline
\end{tabular}

* TAO - Triacetyloleandomycin 
was decreased in females; however, male liver showed only not significant changes in Cyp3all mRNA levels. Conversely, protein expression of CYP3A11 did not differ between female $o b / o b$ mice and control animals; in males, however, significantly decreased CYP3A11 protein expression was observed ${ }^{32}$. The protein and gene expression of CYP3A did not significantly differ between $d b / d b$ mice and C57BL/6 mice (control animals) (ref. ${ }^{21}$ ). On the contrary, a study that used mice with MSG-induced obesity showed increased CYP3A activity and protein levels in the liver of obese mice ${ }^{10}$.

Suh et al. used ZDF rats at 6 weeks as a pre-diabetes model and at 12 weeks as a diabetes model. They observed significantly reduced hepatic CYP3A enzyme activity in 12-week-old ZDF rats compared to Zucker lean controls ${ }^{23}$. As seen from the above comparisons, the findings described in various studies show that CYP regulation is highly dependent on the obesity model, tissue used and other characteristics ${ }^{55}$.

\section{DISCUSSION AND CONCLUSION}

Obesity is a complex metabolic disorder that has become a global health problem. To a large extent, obesity in humans is associated with lifestyle (e.g. excessive intake of calories) rather than genetic defects. Obese patients usually suffer from obesity-related diseases and they are thus dependent on the concomitant use of several drugs. It is absolutely necessary that patients are adequately informed about drugs and their possible drug-drug interactions and adverse reactions that may occur. Nowadays, there is insufficient data about how obesity can affect enzyme activity and expression of CYP enzymes in an individual; therefore, animal obesity models are used as surrogate models of human obesity.

Obesity not only affects the properties of CYP enzymes but it is also associated with the development of different diseases. Obesity is linked to an increased risk of cardiovascular diseases. The BMI is an important factor for classification of overweight and obesity. A recent study $^{56}$ aimed to determine its effect on postoperative outcomes after vascular surgery in humans. The study showed lower rates of mortality and cardiac and respiratory morbidity in obese patients after vascular surgery in comparison with normal patients. Despite this fact, wound complications were more frequent in these obese patients. As already mentioned, the increased incidence of obesity results from various types of cancer. Recent research was focused on exploring the effect of high-fat diet-induced obesity on the growth of orthotopically and subcutaneously injected xenografts of human colon cancer to mice. It was found that human colon carcinoma grew faster in obese and insulin-resistant animals due to consumption of high-fat $\operatorname{diet}^{57}$.

This review summarizes how obesity and obesity-related diseases can affect the properties of CYP enzymes (the main enzymes of drug metabolism), especially in animal models. In studies mentioned in this review, the authors documented that animal models of obesity exhibited al- tered expression of drug-metabolizing enzymes. Several animal models have been developed for the obesity research. However, there are differences within an animal species, in gender or induction of obesity. All these factors may influence the regulation of expression of a particular CYP form. This also most likely explains why various models of animal obesity have given different results.

In general, obesity is (in the majority of experiments with human material) associated with a decrease of CYP activities (except for the CYP2C and CYP2E1 enzymes); similar results were obtained for most CYP results in $o b /$ $o b$ mice. MSG administered to newborn mice usually leads to an increase in CYP expression.

In other words, it is very important to select the most appropriate animal model, most closely resembling the properties studied in the particular case of human obesity. Although several well-designed animal models have demonstrated the association between obesity and activity and expression of CYP enzymes, a clear explanation of the mechanisms of the influence of obesity on liver drug metabolism in humans is still lacking.

\section{Search strategy and selection criteria}

Literature search using the PubMed, Science Direct and Web of Science databases for the years 1984-2016.

Acknowledgment: This work has been supported by the Czech Science Foundation (Centre of Excellence, grant no. P303/12/G163), Internal Student Grant of Palacky University (LF_2016_012) and Ministry of Health, Czech Republic - conceptual development of research organization (FNO1, 00098892).

Author contributions: VT: manuscript writing; PA: critical review of the manuscript; EA: project leadership, critical review of the manuscript

Conflict of interest statement: The authors state that there are no conflicts of interest regarding the publication of this article.

\section{REFERENCES}

1. Monteiro R, Azevedo I. Chronic inflammation in obesity and the metabolic syndrome. Mediators Inflamm 2010;2010.

2. Morrish GA, Pai MP, Green B. The effects of obesity on drug pharmacokinetics in humans. Expert Opin Drug Metab Toxicol 2011;7(6):697706.

3. De Pergola G, Silvestris F. Obesity as a major risk factor for cancer. J Obes 2013;2013:291546.

4. Tahergorabi Z, Khazaei M. The relationship between inflammatory markers, angiogenesis, and obesity. ARYA Atheroscler 2013;9(4):24753.

5. Blouin RA, Warren GW. Pharmacokinetic considerations in obesity. J Pharm Sci 1999;88(1):1-7.

6. Calle EE, Rodriguez C, Walker-Thurmond K, Thun MJ. Overweight, obesity, and mortality from cancer in a prospectively studied cohort of U.S. adults. N Engl J Med 2003;348(17):1625-38.

7. Jain R, Chung SM, Jain L, Khurana M, Lau SW, Lee JE, Vaidyanathan J, Zadezensky I, Choe S, Sahajwalla CG. Implications of obesity for drug therapy: limitations and challenges. Clin Pharmacol Ther 2011;90(1):77-89.

8. Finkelstein EA, Khavjou OA, Thompson H, Trogdon JG, Pan L, Sherry B, Dietz W. Obesity and severe obesity forecasts through 2030. Am J Prev Med 2012;42(6):563-70. 
9. Ghose R. Clinical consequences of altered drug disposition in obesity. J Clin Trials 2013;2:e107.

10. Tomankova V, Liskova B, Skalova L, Bartikova H, Bousova I, Jourova L, Anzenbacher P, Ulrichova J, Anzenbacherova E. Altered cytochrome P450 activities and expression levels in the liver and intestines of the monosodium glutamate-induced mouse model of human obesity. Life Sci 2015;133:15-20.

11. Anzenbacher P, Anzenbacherova E. Cytochromes P450 and metabolism of xenobiotics. Cell Mol Life Sci 2001;58(5-6):737-47.

12. Parkinson A, Ogilvie BW. Biotransformation of xenobiotics: McGrawHill New York 2001.

13. Zanger UM, Schwab M. Cytochrome P450 enzymes in drug metabolism: regulation of gene expression, enzyme activities, and impact of genetic variation. Pharmacol Ther 2013;138(1):103-41.

14. Lynch T, Price A. The effect of cytochrome P450 metabolism on drug response, interactions, and adverse effects. Am Fam Physician 2007;76(3):391-6.

15. Guengerich FP. Cytochromes P450, drugs, and diseases. Mol Interv 2003;3(4):194-204.

16. Martignoni M, Groothuis GM, de Kanter R. Species differences between mouse, rat, dog, monkey and human CYP-mediated drug metabolism, inhibition and induction. Expert Opin Drug Metab Toxicol 2006;2(6):875-94.

17. Ogu CC, Maxa JL. Drug interactions due to cytochrome P450. Proc (Bayl Univ Med Cent) 2000;13(4):421-3.

18. Chiney MS, Schwarzenberg SJ, Johnson LA. Altered xanthine oxidase and $\mathrm{N}$-acetyltransferase activity in obese children. $\mathrm{Br} J$ Clin Pharmacol 2011;72(1):109-15.

19. Brill MJ, Diepstraten J, van Rongen $A$, van Kralingen $S$, van den Anker $\mathrm{JN}$, Knibbe CA. Impact of obesity on drug metabolism and elimination in adults and children. Clin Pharmacokinet 2012;51(5):277-304

20. Watson AM, Poloyac SM, Howard G, Blouin RA. Effect of leptin on cytochrome P-450, conjugation, and antioxidant enzymes in the ob/ ob mouse. Drug Metab Dispos 1999;27(6):695-700

21. Yoshinari K, Takagi S, Sugatani J, Miwa M. Changes in the expression of cytochromes P450 and nuclear receptors in the liver of genetically diabetic db/db mice. Biol Pharm Bull 2006;29(8):1634-8.

22. Hakkak R, Macleod S, Korourian S. Effects of obesity and 7 , 12-dimethylbenz(a)anthracene (DMBA) treatment on liver cytochrome P4501A1 and 1B1 expression in ovariectomized obese Zucker rats. J Mol Genet Med 2013;S1:003.

23. Suh YH, Kim Y, Bang JH, Choi KS, Lee JW, Kim WH, Oh TJ, An S, Jung $\mathrm{MH}$. Analysis of gene expression profiles in insulin-sensitive tissues from pre-diabetic and diabetic Zucker diabetic fatty rats. J Mo Endocrinol 2005;34(2):299-315.

24. Zhang WV, Ramzan I, Murray M. Impaired microsomal oxidation of the atypical antipsychotic agent clozapine in hepatic steatosis. $J$ Pharmacol Exp Ther 2007;322(2):770-7.

25. DuBois BN, O'Tierney-Ginn P, Pearson J, Friedman JE, Thornburg K, Cherala G. Maternal obesity alters feto-placental cytochrome P4501A1 activity. Placenta 2012;33(12):1045-51.

26. Raunio H, Juvonen R, Pasanen M, Pelkonen O, Paakko P, Soini $Y$. Cytochrome P4502A6 (CYP2A6) expression in human hepatocellular carcinoma. Hepatology 1998;27(2):427-32.

27. Raunio H, Rahnasto-Rilla M. CYP2A6: genetics, structure, regulation, and function. Drug Metabol Drug Interact 2012;27(2):73-88.

28. Xu C, Goodz S, Sellers EM, Tyndale RF. CYP2A6 genetic variation and potential consequences. Adv Drug Deliv Rev 2002;54(10):1245-56.

29. Le Gal A, Dreano Y, Lucas D, Berthou F. Diversity of selective environmental substrates for human cytochrome P450 2A6: alkoxyethers, nicotine, coumarin, $\mathrm{N}$-nitrosodiethylamine, and N-nitrosobenzylmethylamine. Toxicol Lett 2003;144(1):77-91.

30. Abu-Bakar A, Arthur DM, Wikman AS, Rahnasto M, Juvonen RO, Vepsalainen J, Raunio H, Ng JC, Lang MA. Metabolism of bilirubin by human cytochrome P450 2A6. Toxicol Appl Pharmacol 2012;261(1):50-8.

31. Donato MT, Jimenez N, Serralta A, Mir J, Castell JV, Gomez-Lechon MJ. Effects of steatosis on drug-metabolizing capability of primary human hepatocytes. Toxicol In Vitro 2007;21(2):271-6.

32. Cheng Q, Aleksunes LM, Manautou JE, Cherrington NJ, Scheffer GL, Yamasaki $\mathrm{H}$, Slitt AL. Drug-metabolizing enzyme and transporter expression in a mouse model of diabetes and obesity. Mol Pharm 2008;5(1):77-91.

33. Turpeinen M, Zanger UM. Cytochrome P450 2B6: function, genetics, and clinical relevance. Drug Metabol Drug Interact 2012;27(4):185-97.
34. Yamanaka H, Nakajima M, Fukami T, Sakai H, Nakamura A, Katoh M, Takamiya M, Aoki Y, Yokoi T. CYP2A6 and CYP2B6 are involved in nornicotine formation from nicotine in humans: interindividual differences in these contributions. Drug Metab Dispos 2005;33(12):1811-8.

35. Xiong H, Yoshinari K, Brouwer KL, Negishi M. Role of constitutive androstane receptor in the in vivo induction of Mrp3 and CYP2B1/2 by phenobarbital. Drug Metab Dispos 2002;30(8):918-23.

36. Goldstein JA. Clinical relevance of genetic polymorphisms in the human CYP2C subfamily. Br J Clin Pharmacol 2001;52(4):349-55.

37. Sweeney BP, Bromilow J. Liver enzyme induction and inhibition: implications for anaesthesia. Anaesthesia 2006;61(2):159-77.

38. Johannessen SI, Landmark CJ. Antiepileptic drug interactions - principles and clinical implications. Curr Neuropharmacol 2010;8(3):25467.

39. Steimer W, Zöpf K, von Amelunxen S, Pfeiffer H, Bachofer J, Popp J, Messner B, Kissling W, Leucht S. Amitriptyline or not, that is the question: pharmacogenetic testing of CYP2D6 and CYP2C19 identifies patients with low or high risk for side effects in amitriptyline therapy. Clin Chem 2005;51(2):376-85.

40. Bertilsson L, Dahl ML, Dalén P, Al-Shurbaji A. Molecular genetics of CYP2D6: clinical relevance with focus on psychotropic drugs. $\mathrm{Br} J$ Clin Pharmacol 2002;53(2):111-22.

41. Cravotto G, Boffa L, Genzini L, Garella D. Phytotherapeutics: an evaluation of the potential of 1000 plants. J Clin Pharm Ther 2010;35(1):1148.

42. Cheymol G, Woestenborghs R, Snoeck E, lanucci R, Le Moing JP, Naditch L, Levron JC, Poirier JM. Pharmacokinetic study and cardiovascular monitoring of nebivolol in normal and obese subjects. Eur J Clin Pharmacol 1997;51(6):493-8.

43. Badyal DK, Dadhich AP. Cytochrome P450 and drug interactions. Indian J Pharmacol 2001;33:248-59.

44. Dostalek M, Court MH, Yan B, Akhlaghi F. Significantly reduced cytochrome P450 3A4 expression and activity in liver from humans with diabetes mellitus. Br J Pharmacol 2011;163(5):937-47.

45. Khemawoot P, Yokogawa K, Shimada T, Miyamoto K. Obesity-induced increase of CYP2E1 activity and its effect on disposition kinetics of chlorzoxazone in Zucker rats. Biochem Pharmacol 2007;73(1):155-62.

46. Enriquez A, Leclercq I, Farrell GC, Robertson G. Altered expression of hepatic CYP2E1 and CYP4A in obese, diabetic ob/ob mice, and fa/fa Zucker rats. Biochem Biophys Res Commun 1999;255(2):300-6.

47. Matalova P, Urbanek K, Anzenbacher P. Specific features of pharmacokinetics in children. Drug Metab Rev 2016;48(1):70-9.

48. Nebert DW, Russell DW. Clinical importance of the cytochromes P450. Lancet 2002;360(9340):1155-62.

49. Wang T, Shankar K, Ronis MJ, Mehendale HM. Mechanisms and outcomes of drug- and toxicant-induced liver toxicity in diabetes. Crit Rev Toxicol 2007;37(5):413-59.

50. Kotlyar M, Carson SW. Effects of obesity on the cytochrome P450 enzyme system. Int J Clin Pharmacol Ther 1999:37(1):8-19.

51. Lemahieu WP, Maes BD, Verbeke K, Vanrenterghem YF. Alterations of CYP3A4 and P-glycoprotein activity in vivo with time in renal graft recipients. Kidney Int 2004;66(1):433-40.

52. Li XS, Nielsen J, Cirincione B, Li H, Addy C, Wagner J, Hartford A, Erondu N, Gantz I, Morgan J, Stone J. Development of a population pharmacokinetic model for taranabant, a cannibinoid-1 receptor inverse agonist. AAPS J 2010;12(4):537-47.

53. Yoshinari K, Takagi S, Yoshimasa T, Sugatani J, Miwa M. Hepatic CYP3A expression is attenuated in obese mice fed a high-fat diet. Pharm Res 2006;23(6):1188-200.

54. Ghose R, Omoluabi O, Gandhi A, Shah P, Strohacker K, Carpenter KC, McFarlin B, Guo T. Role of high-fat diet in regulation of gene expression of drug metabolizing enzymes and transporters. Life Sci 2011;89(1-2):57-64.

55. Gandhi A, Moorthy B, Ghose R. Drug disposition in pathophysiological conditions. Curr Drug Metab 2012;13(9):1327-44.

56. Galyfos G, Geropapas GI, Kerasidis S, Sianou A, Sigala F, Filis K. The effect of body mass index on major outcomes after vascular surgery. J Vasc Surg 2016; pii:S0741-5214(16)31274-5.

57. O'Neill AM, Burrington CM, Gillaspie EA, Lynch DT, Horsman MJ, Greene MW. High-fat Western diet-induced obesity contributes to increased tumor growth in mouse models of human colon cancer. Nutr Res 2016;pii:S0271-5317(16)30565-6.

58. Raunio H, Rautio A, Gullsten H, Pelkonen O. Polymorphisms of CYP2A6 and its practical consequences. $\mathrm{Br} J$ Clin Pharmacol 2001;52(4):357-63. 
59. Bousova I, Matouskova P, Bartikova H, Szotakova B, Hanusova V Tomankova V, Anzenbacherova E, Liskova B, Anzenbacher P, Skalova L. Influence of diet supplementation with green tea extract on drugmetabolizing enzymes in a mouse model of monosodium glutamate-induced obesity. Eur J Nutr 2016;55(1):361-71.

60. Zhang W, Kilicarslan T, Tyndale RF, Sellers EM. Evaluation of methoxsalen, tranylcypromine, and tryptamine as specific and selective CYP2A6 inhibitors in vitro. Drug Metab Dispos 2001;29(6):897-902.

61. Pelkonen O, Rautio A, Raunio H, Pasanen M. CYP2A6: a human coumarin 7-hydroxylase. Toxicology 2000;144(1-3):139-47.

62. Pelkonen O, Maenpaa J, Taavitsainen P, Rautio A, Raunio H. Inhibition and induction of human cytochrome P450 (CYP) enzymes. Xenobiotica 1998;28(12):1203-53.

63. Lewis DFV, Dickins M. Substrate SARs in human P450s. Drug Discov Today 2002;7(17):918-25.

64. Pernecky SJ, Porter TD, Coon MJ. Expression of rabbit cytochrome P-450IIE2 in yeast and stabilization of the enzyme by 4-methylpyrazole. Biochem Biophys Res Commun 1990;172(3):1331-7.

65. Kenworthy K, Bloomer J, Clarke S, Houston J. CYP3A4 drug interactions: correlation of 10 in vitro probe substrates. Br J Clin Pharmacol 1999;48(5):716-27.

66. Patoine D, Petit M, Pilote S, Picard F, Drolet B, Simard C. Modulation of CYP3a expression and activity in mice models of type 1 and type 2 diabetes. Pharmacol Res Perspect 2014;2(6):e00082.

67. Furuta T, Shirai N, Takashima M, Xiao F, Hanai H, Sugimura H, Ohashi $\mathrm{K}$, Ishizaki T, Kaneko E. Effect of genotypic differences in CYP2C19 on cure rates for Helicobacter pylori infection by triple therapy with a proton pump inhibitor, amoxicillin, and clarithromycin. Clin Pharmacol Ther 2001;69(3):158-68.

68. Koudriakova T, latsimirskaia E, Utkin I, Gangl E, Vouros P, Storozhuk E, Orza D, Marinina J, Gerber N. Metabolism of the human immunodeficiency virus protease inhibitors indinavir and ritonavir by human intestinal microsomes and expressed cytochrome P4503A4/3A5: mechanism-based inactivation of cytochrome $\mathrm{P} 4503 \mathrm{~A}$ by ritonavir. Drug Metab Dispos 1998;26(6):552-61.

69. Warrington JS, Shader RI, von Moltke LL, Greenblatt DJ. In vitro biotransformation of sildenafil (Viagra): identification of human cytochromes and potential drug interactions. Drug Metab Dispos 2000;28(4):392-7.

70. Delaforge M, Jaouen M, Mansuy D. The cytochrome P-450 metabolite complex derived from troleandomycin: properties in vitro and stability in vivo. Chem Biol Interact 1984;51(3):371-6.
71. Kanasaki K, Koya D. Biology of obesity: lessons from animal models of obesity. J Biomed Biotechnol 2011;2011.

72. Kim S, Sohn I, Ahn JI, Lee KH, Lee YS, Lee YS. Hepatic gene expression profiles in a long-term high-fat diet-induced obesity mouse model. Gene 2004;340(1):99-109.

73. Lutz TA, Woods SC. Overview of animal models of obesity. Curr Protoc Pharmacol 2012; Chapter 5:Unit5.61.

74. Bultman SJ, Michaud EJ, Woychik RP. Molecular characterization of the mouse agouti locus. Cell 1992;71(7):1195-204.

75. Chen D, Garg A. Monogenic disorders of obesity and body fat distribution. J Lipid Res 1999;40(10):1735-46.

76. O'Rahilly S. Human genetics illuminates the paths to metabolic disease. Nature 2009;462(7271):307-14.

77. Speakman J, Hambly C, Mitchell S, Krol E. Animal models of obesity. Obes Rev 2007;8(s1):55-61.

78. Fowler MJ. Microvascular and macrovascular complications of diabetes. Clin Diabetes 2008;26(2):77-82.

79. Collins S, Martin TL, Surwit RS, Robidoux J. Genetic vulnerability to diet-induced obesity in the $\mathrm{C} 57 \mathrm{BL} / 6 \mathrm{~J}$ mouse: physiological and molecular characteristics. Physiol Behav 2004;81(2):243-8.

80. Nilsson C, Raun K, Yan FF, Larsen MO, Tang-Christensen M. Laboratory animals as surrogate models of human obesity. Acta Pharmacol Sin 2012;33(2):173-81.

81. Hariri N, Thibault L. High-fat diet-induced obesity in animal models. Nutr Res Rev 2010;23(2):270-99.

82. Lin S, Thomas TC, Storlien LH, Huang XF. Development of high fat diet-induced obesity and leptin resistance in $\mathrm{C} 57 \mathrm{BI} / 6 \mathrm{~J}$ mice. Int J Obes 2000;24(5):639-46.

83. Islam MS, Wilson RD. Experimentally induced rodent models of type 2 diabetes. Methods Mol Biol 2012;933:161-74.

84. LeRoith D, Taylor SI, Olefsky JM. Diabetes mellitus: a fundamental and clinical text: Lippincott Williams \& Wilkins 2004.

85. Lobato NS, Filgueira FP, Akamine EH, Davel AP, Rossoni LV, Tostes $\mathrm{RC}$, Carvalho MH, Fortes ZB. Obesity induced by neonatal treatment with monosodium glutamate impairs microvascular reactivity in adult rats: role of NO and prostanoids. Nutr Metab Cardiovasc Dis 2011;21(10):808-16.

Supplemental Material: The online version of this article (doi: 10.5507/bp.2017.026) offers supplemental material. 